\title{
Early verb development in one Russian-speaking child ${ }^{1}$
}

\author{
Natalia Gagarina \\ Berlin/St. Petersburg \\ gagarina@zas.gwz-berlin.de
}

\section{Introduction}

This paper investigates the development of verbal inflection in the early stages of the acquisition of Russian. Data from tape recordings and a diary were used for this study.

\section{Verb morphology in the target language}

Russian is known to have 'rich' verbal morphology. The main categories are presented in Table $1^{2}$ :

\begin{tabular}{|c|c|c|c|c|c|c|}
\hline & \multirow{2}{*}{\multicolumn{3}{|c|}{$\begin{array}{c}1 \\
\text { Finite forms }\end{array}$}} & 2 & \multicolumn{2}{|c|}{3} \\
\hline & & & & Infinitive & Participle & Verbal adverb \\
\hline $\begin{array}{c}\text { aspect } \\
\text { (PF and IPF) }\end{array}$ & & + & & + & + & + \\
\hline $\begin{array}{c}\text { voice } \\
\text { (active, passive) }\end{array}$ & & + & & + & + & + \\
\hline $\operatorname{mood}$ & indicative & imperative & conditional & & & \\
\hline $\begin{array}{c}\text { tense } \\
\text { (past, present, future) }\end{array}$ & + & - & - & - & pres. and past & pres. and past \\
\hline $\begin{array}{c}\text { person } \\
\left(1^{\text {st }}, 2^{\text {nd }}, 3^{\mathrm{d}}\right) \\
\end{array}$ & $\begin{array}{c}+ \\
\text { (except past) } \\
\end{array}$ & (only $2^{+ \text {idd }}$ pers.) & - & - & - & - \\
\hline $\begin{array}{c}\text { number } \\
(\mathrm{SG}, \mathrm{PL})\end{array}$ & & + & & - & + & - \\
\hline $\begin{array}{c}\text { gender } \\
\text { (masc., fem.,neutr.) }\end{array}$ & $\stackrel{+}{+}+\mathrm{SG}-$ in the past) & - & + & - & + & - \\
\hline
\end{tabular}

Three tenses - past, present and future - are distributed between two aspects - perfective (PF) and imperfective (IPF) - in the following way:

$\begin{array}{lll} & \text { PF } & \text { IPF } \\ \text { Past } & + & + \\ \text { Present } & - & + \\ \text { Future } & + & +(b y t \text { ' 'to be' + main verb in the infinitive })\end{array}$

Forms of IPF in present and of PF in future (also the auxiliary byt' 'to be' in the compound future with IPF) have three persons in SG and PL (no person distinction in the past), past forms are marked for gender (only in SG) and number.

One important peculiarity of the inflectional system is the presence of two bases for the verbs. Open base (OB) (often stem-based) usually ends in a Vowel, e.g., smotr'-e-t' - 'to look', igr$a-t$ '- 'to play' and serves as platform to build past tense forms. Close base (CB) (often rootbased) ends in consonant: smotr'-u - 'look-1.SG.PRES.', igr-aj-u - 'play-1.SG.PRES'. Forms of present/future in the indicative and imperative are constructed from this base. Alternations

I I would like to thank Wolfgang U. Dressler and Dagmar Bittner for their helpful comments on the earlier version of this paper. I express my gratitude to Paul Law for his suggestions concerning formulation and stylistics. All errors are mine.

2 Participle, verbal adverb and forms in the conditional mood as well as in the passive voice do not occur in the period under our observation. 
between $\mathrm{OB}$ and $\mathrm{CB}$ can be said to be an important base for constructing forms of the paradigms and inflectional classes.

Table 2: The paradigm ${ }^{3}$ of one aspectual counterpart of the verb obedat'-IPF/poobedat'-PF 'to have lunch'. OB obeda-/poobeda- is presented in the table only by the last sound ..a-, CB obedaj-/poobedaj- is presented by ..aj-:

\begin{tabular}{|c|c|c|c|c|c|c|c|c|c|c|c|c|c|c|}
\hline \multirow{3}{*}{$\begin{array}{l}\text { a } \\
\mathrm{s} \\
\mathrm{p}\end{array}$} & \multirow[t]{3}{*}{ infin. } & \multicolumn{2}{|c|}{ imperative } & \multicolumn{6}{|c|}{$\begin{array}{c}\text { present tense } \\
\text { (for PF forms - future) }\end{array}$} & \multicolumn{4}{|c|}{ past tense } & \multirow{3}{*}{ 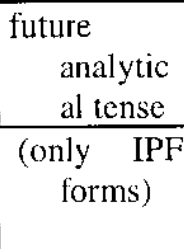 } \\
\hline & & \multirow{2}{*}{$\begin{array}{c}2 . \\
\text { SG }\end{array}$} & \multirow{2}{*}{2.} & \multicolumn{3}{|c|}{ SG } & \multicolumn{3}{|c|}{ PL } & \multicolumn{3}{|c|}{ SG } & \multirow[t]{2}{*}{ PL } & \\
\hline & & & & 1. & 2. & 3. & 1. & 2. & 3. & femin. & mase. & neutr. & & \\
\hline $\begin{array}{l}\text { l } \\
\text { P } \\
\text { F }\end{array}$ & $\begin{array}{l}\text { obe- } \\
\text { da-t' }\end{array}$ & ..aj & ..aj-te & $. . \mathrm{aj}-\mathrm{u}$ & ..aj-ešs: & ..aj-et & ..aj-cm & ..aj-ete & ..aj-ut & ...a-l-a & $. . \mathrm{a}-\mathrm{l}$ & ..a-1-o & $. . \mathrm{a}-\mathrm{l}-\mathrm{i}$ & $\begin{array}{c}\text { byt' } \\
\text { (inflected - } \\
\text { 1.2.3.SG or } \\
\text { 1.2.3.PL) + } \\
\text { infinitive } \\
\text { obeda-t' }\end{array}$ \\
\hline $\begin{array}{l}\mathrm{P} \\
\mathrm{F}\end{array}$ & $\begin{array}{l}\text { po- } \\
\text { obe- } \\
\text { dat' }\end{array}$ & ..aj & ..aj-te & $. a j-u$ & ..aj-čs' & .aj-et & ..aj-em & ..aj-ete & ..aj-ut & $. . a-1-a$ & $. . \mathrm{a}-\mathrm{l}$ & ..a-l-o & ..a-l-i & \\
\hline
\end{tabular}

The traditional alternation between an OS of the infinitive and the CS of the present/future (1.SG) has been taken by us as a platform to define 45 inflectional microclasses (see Dressler and Gagarina 1999). Only four of them are fully productive:

$1^{\text {st }}$ (alternation between OB and CB is a/aj), obeda $-t^{\prime}$ - obedaj- $u$ 'to have dinner',

$7^{\text {th }}$ (with the alternation: ova/uj), risova-t' - risuj- $u$ 'to draw',

$17^{\text {th }}$ (with the alternation: consonant $+\mathrm{i} /$ consonant), kuri-t' $-k u r^{\prime}-u$ 'to smoke',

$38^{\text {th }}$ (with the alternation consonant + vowel is part of the pluriphonemic thematic suffix $n u$ /consonant $n$ ), prygnu-t'- prygn- $u$ 'to jump once'. In the data for early verbs we found lemmas from 15 different classes, as well as isolated paradigms, such as odet' 'to put on clothes, shoes', est'- em 'to eat', dat' - dam 'to give' and others. The first productive class is represented by the majority of lemmas, such as pryga $-t^{\prime}$ - prygaj- $u$ 'to jump', vkl'ucha-t' - vkl'uchaj-u 'to switch on', etc.

The other MCs are represented only by two (rarely three) verbs (lemmas):

$6^{\text {th }}$ (stem alternation: $\left.y / o j\right) m y-t^{\prime}-m o j-u$ 'to wash',

$9^{\text {th }}$ (stem alternation: $\left.\mathrm{va} / \mathrm{j}\right) d a v a-t^{\prime}$ - $d a j-u$ 'to give',

$11^{\text {th }}$ (stem alternation: a/an (an')) vsta-t' - vstan- $u$ 'to stand up',

$12^{\text {th }}$ (stem alternation: ja/j) stoja-t' - stoj- $u$ 'to stand',

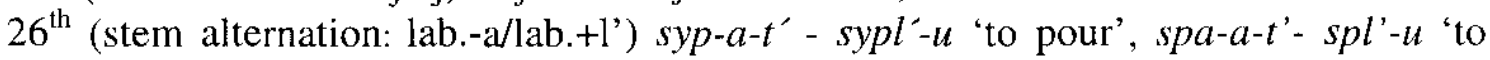
sleep',

The following MCs were represented only by one verb:

one slightly productive $\mathrm{MC}$ :

$2^{\text {nd }}$ (stem alternation: e/ej) bole-t' - bolej- $u$ 'to be sick',

four unproductive MCs:

$22^{\text {nd }}$ (stem alternation: $\mathrm{s}+\mathrm{a} / \check{\mathrm{s}}$ ) pisa-t' $-p i \breve{\mathrm{s}}-u$ 'to write'

$30^{\text {th }}$ (stem alternation: $\mathrm{de} / \bar{z}$ ) $s^{\prime} i d^{\prime} e-t^{\prime}$ - $s i z ̌-u$ 'to sit',

$32^{\text {nd }}$ (stem alternation: $\mathrm{ti} / \check{\mathrm{c}}$ ) $k r u t-i-t^{\prime}-k r u \check{c}-u$ 'to turn',

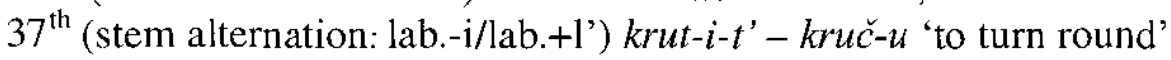

3 The forms of participle and verbal adverb are not given in the table. 


\section{Data description}

We used longitudinal recordings and diary notes of one male child - Roma F., the only child in a middle-class family in St. Petersburg, where standard "Petersburg" version of colloquial Russian is spoken. The whole corpus consists of about 18,3 hours (about $1100 \mathrm{~min}$ ) of recordings during the period from 1;01.07. till 2;11.03. For this report we used only the speech of Roma that was registered between $1 ; 10$ and $2 ; 01$ - the emergence of verbal inflection (38 lemmas). During the period 2;00 and 2;01 Roma has been recorded nine times (with an interval seven-nine days in the middle of the month) per month. Sessions were grouped into files $2 ; 00 \mathrm{a} / 2 ; 00 \mathrm{~b}$ and files $2 ; 01 \mathrm{a} / 2 ; 01 \mathrm{~b}$ respectively.

Table 3.0. describes the data (recordings) in the period under investigation:

\begin{tabular}{|c|c|c|c|}
\hline age & duration & $\begin{array}{c}\text { production (only for } \\
\text { recordings) }\end{array}$ & analysed utterances $^{4}$ \\
\hline $1 ; 10$ & $57 \mathrm{~min}$ & 200 & 154 \\
\hline $1 ; 11$ & $133 \mathrm{~min}$ & 612 & 419 \\
\hline $2 ; 00 \mathrm{a}$ & $125 \mathrm{~min}$ & $\sim 422^{5}$ & 359 \\
\hline $2 ; 00 \mathrm{~b}$ & $76 \mathrm{~min}$ & $\sim 498$ & 415 \\
\hline $2 ; 01 \mathrm{a}$ & $60 \mathrm{~min}$ & $\sim 429$ & 388 \\
\hline $2 ; 01 \mathrm{~b}$ & $27 \mathrm{~min}$ & $\sim 119$ & 112 \\
\hline Total & $\mathbf{8}$ hours & $\mathbf{2 2 8 0}$ & $\mathbf{1 8 4 7}$ \\
\hline
\end{tabular}

Beginning with the age of $2 ; 02$, when the crucial development continues, we have, unfortunately, the gap in the recordings. Hence, we considered, additionally, diary notes. Diary may help us to reproduce more or less full picture of early development of Roma's verb categories. At the age of 2;00 and 2;01 the mother carefully noted sentences, that maintain new constructions, lexical items, inflectional forms, etc. Since the aim of this paper is to trace the emergence of new verbs and their forms in the speech of Roma, we suppose that use of diary will enrich the picture of verb development. Generally, the results of the investigation of speech production in the diary do not contradict such recordings. Transcription and coding of data was done in CLAN format.

Table 3.1. describes the corpus of the diary used in this study:

\begin{tabular}{|c|c|}
\hline age & analysed utterances \\
\hline $2 ; 00$ & 90 \\
\hline $2 ; 01$ & 147 \\
\hline $2 ; 02$ & 71 \\
\hline Total & $\mathbf{3 0 8}$ \\
\hline
\end{tabular}

Although the amount of data that we have in our disposal is not representative, we worked them up and, in the analysis below, we will try to show that from $1 ; 10$ to 2;01 Roma passes through a stage of premorphology and 'enters' the protomorphological phase. We suppose that the premorphological phase covers the period between $1 ; 10-2 ; 00 \mathrm{a}$ and the protomorphological phase - between $2 ; 00 b-2 ; 01 b$ ( $2 ; 02$ in the diary).

\section{Predecessors of verbs in predicative function}

From the age of 1;05 Roma uses sound-imitations to denote different events. However, at $1 ; 05$ and a couple of months later the situations which Roma describes cannot be divided into components and it is not possible to decide, whether used sound-imitations correspond to a

4 Interjections, citations, direct repetitions, non-comprehensible utterances were excluded from the analysis.

5 The sign $\sim$ shows the approximate number of utterances produced by Roma. There were some ambiguous cases, when it was difficult to decide whether the child said two separate sentences or only one sentence. We count such ambiguous cases as two different utterances. 
predicate or sa subject. In this period the sentences consist mainly form one word and it is difficult to decide whether Roma used a predecessor of a verb or of a noun:

$1 ; 06.17$

- am (denotes meal, process of eating) Roma answers the question: Are you going to eat?

- $\quad$ kkhh (imitates the sound of a moving car, answers the question: Where were you with your father?)

$1 ; 07.21$

- aa-aa (used in different situations, may denote sleeping, also the sleeping dog)

- igogo [ihohó] (used in different situations; may denote a horse or the sound produced by a horse)

We also found some words that slightly resemble verbs (verb-roots) of the adult language and were used by Roma in situations of demand:

$1 ; 05.09$

- adi-di (Roma approaches the TV set, points to it, tries to push buttons and looking at the mother with the intonation of a demand says: 'Adi-di!'). The mother interprets this utterance as a demand to switch on TV - vkljuchi! - 'switch on!'

- at'i - Roma stays at the closed door of the room, tries to open it, does not manage to do it, becomes upset and turning to his mother says: 'At'i!'. This word may resemble otkryt' 'to open')

Later on, after the age of 1;08 we found more sound-imitations that may be more clearly interpreted as predecessors of verbs. For example, at 1;08.12 Roma answers his mother's question: How does a cat do it?

- mjau (sound-imitation of cats).

The context set up by the mother in the last utterance determines predicative meaning of the sound-imitation used by the child.

After the age of 1;10 Roma continues to use sound-imitations (together with the verbs from the adult language) while denoting mainly telic actions with a clear perceived result, e.g., bum, bax were used at the same time as the verb, denoting the same action: upast'-PF 'to fall down'. In the present data we did not find a significant amount of sound-imitations, however, we have more evidence that some children use them for longer period and even use soundimitations variously in order to differentiate between achievements and activities (and states) (see Gagarina 2000). Use of sound-imitations during early phases of the acquisition of inflectional morphology can be said to be a jumping-off place for some children to acquire, for example, aspectual distinctions among the verbs.

\section{Emergence of verb forms}

\subsection{Quantitative data}

First verbs emerge parallel to sound-imitations and words of "baby-talk"6. Almost all verbs forms are inflected, and it is easy to distinguish from the beginning between verbs of two aspects: PF and IPF. There is only a little amount of the unclear and the frozen forms in our data. Besides Roma uses a high number of infinitives in order to express his demands. Such

6 Interesting to note that in Russian the period from the emergence of first verbs till the emergence of early mini-paradigms (MP) is relatively short (in comparison with some other languages, sce articles of this volume). 
infinitives coexist with correct imperatives (also during the later period). We do not think that these infinitives play any significant role in mastering inflectional morphology of verbs, and we do not have enough evidence (in our data) that these infinitives "are used to refer to the past, present and future events in Russian child speech" (see Brun, Avrutin and Babyonyshev 1999).

Table $4^{7}$ shows the emergence and the increase of verb production:

\begin{tabular}{|c|c|c|c|}
\hline age & analysed utterances & utter. with verbs & utter. with verbs \% \\
\hline $1 ; 10$ & 154 & 4 & 2,6 \\
\hline $1 ; 11$ & 419 & 29 & 6,9 \\
\hline $2 ; 00 \mathrm{a}$ & 359 & 22 & 6,1 \\
\hline $2 ; 00 \mathrm{~b}$ & 415 & 50 & 12,0 \\
\hline $2 ; 01 \mathrm{a}$ & 388 & 68 & 17,5 \\
\hline $2 ; 01 \mathrm{~b}$ & 112 & 24 & 21,4 \\
\hline Total & $\mathbf{1 8 4 7}$ & $\mathbf{1 9 7}$ & Average \%: 11,08 \\
\hline
\end{tabular}

Beginning with the age of two (at 2;00b) one can clearly see the developmental spurt (see also Table 5 and Table 6 below). The number of utterances with verbs increases from 22 at 2;00a to 50 at $2 ; 00 \mathrm{~b}$ and reaches $12 \%$ of all utterances.

The more detailed Table 5 and Table 6 (and Diagram 1, Diagram 2 respectively) below demonstrate the amount of inflected lemmas ${ }^{8}$ and tokens in relation to the amount of analysed utterances in recordings and diary:

Table 5 - recordings

\begin{tabular}{|c|c|c|c|c|c|c|}
\hline age & $\begin{array}{c}\text { analysed } \\
\text { utter. }\end{array}$ & aspect $^{9}$ & lemmas & tokens & $\begin{array}{c}\text { lemmas } \\
\%\end{array}$ & $\begin{array}{c}\text { tokens } \\
\%\end{array}$ \\
\hline \multirow[t]{3}{*}{$1 ; 10$} & 154 & IPF & 1 & 1 & 0,6 & 0,6 \\
\hline & & $\mathrm{PF}$ & 2 & 3 & 1,3 & 1,9 \\
\hline & & all verbs & 3 & 4 & 1,9 & 2,6 \\
\hline \multirow[t]{3}{*}{$1 ; 11$} & 419 & IPF & 2 & 2 & 0,5 & 0,5 \\
\hline & & $\mathrm{PF}$ & 4 & 27 & 0,9 & 6,4 \\
\hline & & all verbs & 6 & 29 & 1,4 & 6,9 \\
\hline \multirow[t]{3}{*}{$2 ; 00 \mathrm{a}$} & 359 & IPF & 2 & 3 & 0,6 & 0,8 \\
\hline & & $\mathrm{PF}$ & 5 & 19 & 1,4 & 5,3 \\
\hline & & all verbs & 7 & 22 & 1,9 & 6,1 \\
\hline \multirow[t]{3}{*}{$2 ; 00 \mathrm{~b}$} & 415 & IPF & 7 & 18 & 1,7 & 4,3 \\
\hline & & $\mathrm{PF}$ & 10 & 32 & 2,4 & 7,7 \\
\hline & & all verbs & 17 & 50 & 4,09 & 12,0 \\
\hline \multirow[t]{3}{*}{$2 ; 01 \mathrm{a}$} & 388 & IPF & 9 & 26 & 2,3 & 6,7 \\
\hline & & $\mathrm{PF}$ & 7 & 42 & 1,8 & 10,8 \\
\hline & & all verbs & 16 & 68 & 4,12 & 17,5 \\
\hline \multirow[t]{3}{*}{$2 ; 01 \mathrm{~b}$} & 112 & IPF & 14 & 20 & 12,5 & 17,9 \\
\hline & & $\mathrm{PF}$ & 3 & 4 & 2,7 & 3,6 \\
\hline & & all verbs & 17 & 24 & 15,2 & 21,4 \\
\hline
\end{tabular}

7 The double bold horizontal line in the middle of the Table demarcates pre- and protomorphological phases.

8 Frosen forms are not included into calculations. Analytic forms are not analysed.

9 We separately calculated PF and IPF verbs in order to create a quantitative base for further study of verbal aspect and to trace the emergence of PF and IPF verbs separately. 
Table 6 - diary

\begin{tabular}{|c|c|c|c|c|c|c|}
\hline agc & $\begin{array}{c}\text { analysed } \\
\text { utter. }\end{array}$ & aspect & lemmas & tokens & $\begin{array}{c}\text { lemmas } \\
\%\end{array}$ & $\begin{array}{c}\text { tokens } \\
\%\end{array}$ \\
\hline $2 ; 00$ & 90 & IPF & 6 & 6 & 6,7 & 6,6 \\
\hline & & PF & 3 & 12 & 3,3 & 13,3 \\
\hline & & all verbs & $\mathbf{9}$ & $\mathbf{1 8}$ & $\mathbf{1 0 , 0}$ & $\mathbf{2 0 , 0}$ \\
\hline $2 ; 01$ & 147 & IPF & 25 & 37 & 17,0 & 25,2 \\
\hline & & PF & 11 & 13 & 7,5 & 8,8 \\
\hline & & all verbs & $\mathbf{3 6}$ & $\mathbf{5 0}$ & $\mathbf{2 4 , 5}$ & $\mathbf{3 4 , 0}$ \\
\hline $2 ; 02$ & 71 & IPF & 16 & 20 & 22,5 & 28,2 \\
\hline & & PF & 7 & 14 & 9,9 & 19,7 \\
\hline & & all verbs & $\mathbf{2 3}$ & $\mathbf{3 4}$ & $\mathbf{3 2 , 4}$ & $\mathbf{4 7 , 9}$ \\
\hline
\end{tabular}

Diagram 1 corresponds to Table 5 - recordings

Diagram 2 corresponds to Table 6 - diary

The number of IPF verbs is lower than of PF verbs (except 2;01 a and 2;01b) in the recordings
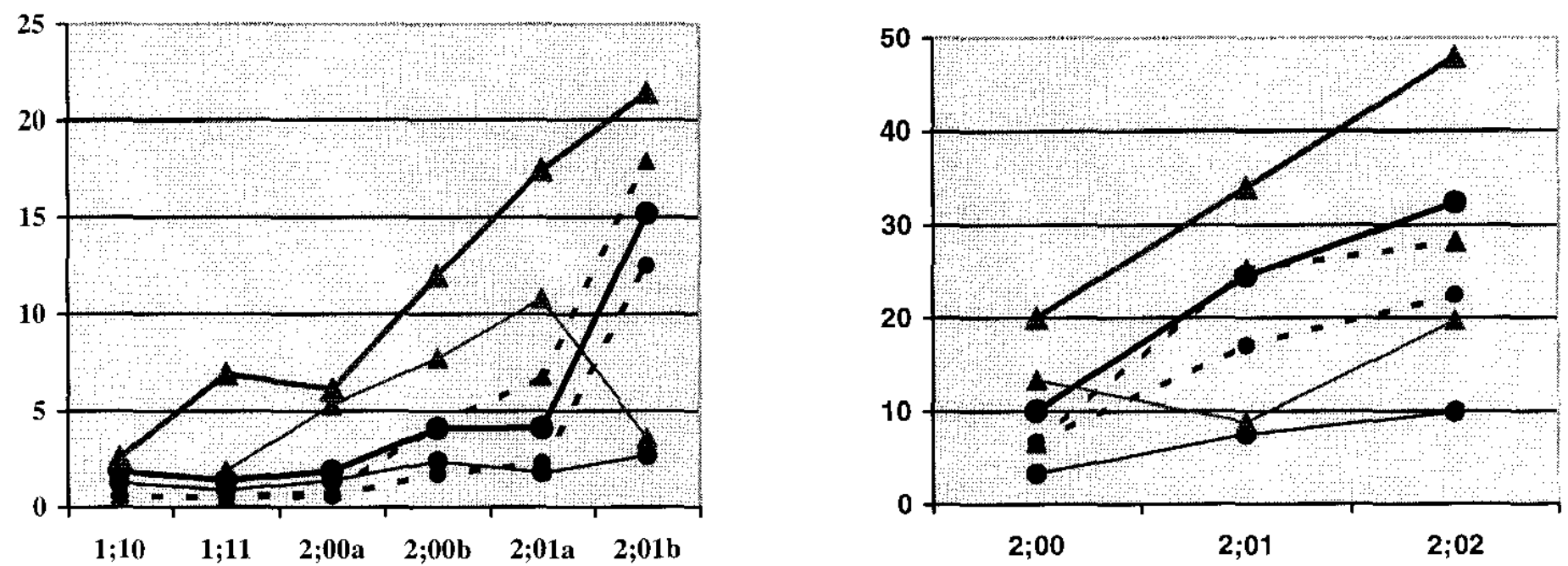

- lemmas - ip $\longrightarrow$ lemmas - pf $\longrightarrow$ lemmas

tokens -ip tokens - pf tokens

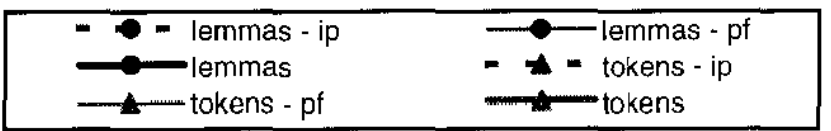

(see Table 5 and Diagram 1); the situation differs in diary notes (see Table 6 and Diagram 2) where more sentences with PFs were registered. Although the morphemic structure of IPF verbs is simpler (these verbs consist mainly of a root and a thematic vowel), they are less frequent (lemmas and tokens) in our data. It seems that PF verbs are more "pragmatically important" for the child, they denote resultative actions with a clearly perceived results, which were performed or witnessed by Roma. The number of tokens of IPF verbs is two times higher than the number of lemmas. The situation differs if we compare lemmas and tokens of PF verbs: the number of tokens is four times higher than the number of lemmas.

After 2;01a the number of lemmas and tokens of both PF and IPF verbs increases more sharply. 


\subsection{Phases of development}

We suppose that in the period under investigation Roma passes the phase of pre-morphology and enters the protomorphological phase ${ }^{10}$. Several processes in the development of verb inflection and changes in speech production can support this supposition.

\subsubsection{Premorphological phase}

We claim that the premorphological phase lasts for about two and a half months: from $1 ; 10$ to the second half of $2 ; 00$ (in the data - stretch $2 ; 00 a$ ).

The number of produced verbs, as we see from Table 5 (Diagram 1), is slowly increasing from three at $1 ; 10$ to seven by the age of 2;00a. No signs of detecting morphological rules and process of self-construction of inflectional forms are traced. During this period six types of inflected rote-learnt forms were used, namely: infinitive, imperative (2. SG), present 3.SG and past SG.masculine, SG.feminine and PL (see Table 5.1. and Table 6.1. in Appendix).

Although at the age of 1;11 Roma used three past forms of one lemma - upast' PF verb 'to fall down':

$\begin{array}{lll}\text { upal } & \text { upala } & \text { upali } \\ \text { PAST.MASC. } & \text { PAST.FEM. } & \text { PAST.PL } \\ 12 \text { times } & 6 \text { times } & 1 \text { time }\end{array}$

we do not maintain, that this is a true mini-paradigm (MP) (see criteria elaborated by KilaniSchock \& Dressler 2000) (explanation see below in (6)).

Two different forms of verbs pit'-IPF 'to drink' (5th MC) and spat'-IPF 'to sleep' (26th MC), infinitive and 3.SG. occur. In order to produce these forms the child has to switch between $\mathrm{OB}$ and $\mathrm{CB}$. Due to the small number of lemmas with two forms mainly appearing with 3.SG.present (rarely PL.), past (SG. and PL.) inflection and in the imperative, we cannot claim that such forms are really "constructed" by the child and are not rote-learnt.

During the premorphological phase some frozen forms were used: davaj-IPF.IMP - 'let us do soemthing', napisan-PF.PAST.PARTIC. - 'is/was/has been written', etc. Interesting to note that some frozen forms escaped from Roma's lexicon during the next stages of the morphological development (for example, participles), while others were used productively (for example, forms of imperative).

\subsubsection{Protomorphological phase}

Beginning from the age corresponding to the group of sessions united under $2 ; 00 \mathrm{~b}$ Roma enters, as we claim, the protomorphological phase.

At 2;00b the child uses seventeen lemmas (seven IPF plus ten PF) (see Table 5); four new types of inflected forms (IPF - past.SG and present.3.SG and PF - future.2.SG and 3.SG) (see Table 5.1. Appendix) occur. The number of lemmas that have two to four forms increase from one to seven. However, some of the verbs, as we suppose, are still strongly connected with the denoted situations (context-dependent). For example, Roma often uses two forms of the verb 'to give' dat'-PF.INF (two times in recordings, one time in diary) and daj-PF.IMP.2.SG. (five

10 About some problems of demarcation between pre- and protomorphology see, for example, Kilani-Schock et al. (1997). 
time in recordings, nine times in diary). However, this verb is used in similar situations, when Roma wants to get something or to open a box ${ }^{11}$.

At this period first three- and four member paradigms emerge. IPF verb kopat' 'to dig' occurs not only in the infinitive and imperative, but also with the 3.SG inflection; the PF verb poexat' 'to start going by car' appears in four inflected forms: $2 . S G$ and $3 . S G$ of the present and feminine and masculine of the past. Roma starts to use more actively both $\mathrm{OB}$ and $\mathrm{CB}$ for constructing different inflected forms.

At 2;01b six new lemmas (five IPF plus one PF) occur, the amount of inflectional types increases to nine (forms of 1.SG and 1.PL emerge). The mother notes in the diary the emergence of the imperfective future - budet ščitat' 'will-3.SG count' and budet streljat' 'will-3.SG shoot'. Roma starts to construct analytical morphological forms. Thirteen verbs are used in two or more inflected forms. Only two verbs with one root (with and without prefixes) were registered - exat' 'to do by car' and poexat' 'to start going by car'. The prefixed verb denotes Roma's intention to start the movement. During this period two component sentences with subjects and objects in pre- and postverbal positions emerge. However, their number is not significant enough to make any conclusions.

\section{Emergence of forms and categories}

\subsection{Emergence of forms}

Table 7 Emergence and use of the infinitive and the finite forms ${ }^{12}$

\begin{tabular}{|c|c|c|c|c|c|c|c|c|c|c|}
\hline Infinitive & Aspect & \multicolumn{6}{|c|}{ Recordings } & \multicolumn{3}{|c|}{ Diary } \\
\hline & & $1 ; 10$ & $1 ; 11$ & $2 ; 00 a$ & $2 ; 00 \mathrm{~b}$ & $2 ; 01 \mathrm{a}$ & $2 ; 01 \mathrm{~b}$ & $2 ; 00$ & $2 ; 01$ & $2 ; 02$ \\
\hline infinitive & IPF & & & & & $1 *$ & $2 *$ & & & \\
\hline & $\mathrm{PF}$ & 8 & & & $m$ & & men & 18 & & \\
\hline
\end{tabular}

\begin{tabular}{|c|c|c|c|c|c|c|c|c|c|c|}
\hline Finite forms & Aspect & \multicolumn{6}{|c|}{ Recordings } & \multicolumn{3}{|c|}{ Diary } \\
\hline past. SG & $\mathrm{PF}$ & 9. & (7) & 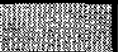 & 12 & 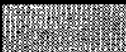 & 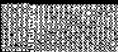 & 17. & 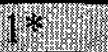 & \\
\hline pres. 3.SG & IPF & & & & & & & 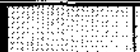 & & \\
\hline past. PL & $\mathrm{PF}$ & & 111 & & 6 & & 111 & & & \\
\hline imper. 2.SG & IPF & & & & & & A & & & \\
\hline & $\mathrm{PF}$ & & & & 6788 & 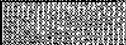 & & & & \\
\hline past. SG & IPF & & & & $1 / 1$ & & & & & \\
\hline pres. 3.PL & IPF & & & & 111 & $1 / 1$ & & & & \\
\hline future 3.SG & $\mathrm{PF}$ & & & & 1 1/1 & & & & & \\
\hline future $2 . S G$ & $\mathrm{PF}$ & & & & $1 / 1$ & & & & & \\
\hline future 1.SG & $\mathrm{PF}$ & & & & & 1/1) & & & & \\
\hline imper. 2.PL & IPF & & & & & 14 & & & & \\
\hline pres. 1.SG & IPF & & & & & & & & & \\
\hline future 1.PL & $\mathrm{PF}$ & & & & & & & & 觔 & \\
\hline anal. future & IPF & & & & & & & & & \\
\hline
\end{tabular}

11 Other children use this verb if they want something to start working or to switch on/off the light or to reach any result.

12 Double bold line in the middle demarcales two phases: pre- and protomorphology. The sign * shows agreement errors, the figure before it shows the number of agreement errors. $1 / 1$ means that one lemma was used only once. Dark shadow corresponds to PF verbs, and light shadow - to IPF verbs. 
Infinitives are the first to occur in Roma's speech and are very 'stable', they are used along with inflected forms in the period under observation. Thus, the child uses correct imperative $v k l j u c h i$ 'to switch on' and at the same time - infinitive vkljuchi-t' (which is also correct in the target language but much less frequent). Most infinitives are used in one-component utterances:

1;11 Roma tries to put on his shoe, he does not manage, turns to his mother and says:

*ROM: $\quad$ Odet'

put on-INF

2;00a Roma is tired and rubbing his eyes, repeats:

*ROM: Spat' spat'.

sleep-INF sleep-INF

We found one case in which the use of infinitive maybe interpreted as a general denotation of the action (in the commentaries to the recordings mother notes that Roma does not want to drink):

2;00a Roma and mother are reading a magazine. The mother points to the picture:

$\begin{array}{lll}\text { *MAM: } & \begin{array}{l}\text { Tam kofe } \\ \text { there coffee }\end{array} & \begin{array}{l}\text { smotri } \\ \text { look-IMP }\end{array} \\ \text { *ROM: } & \begin{array}{l}\text { Pit' } \\ \text { drink-INF }\end{array}\end{array}$

However the mentioned case is only one in our data. Usually Roma uses infinitives in situations of demand. The use of infinitives in our data does not support ideas of Brun, Avrutin \& Babyonyshev (1999), who claim that in the early stages of language acquisition children use infinitives in order to mark tense and aspect. Aspect is an 'inherent' property of a root (or stem with a prefix and a suffix) and cannot be expressed through infinitives.

There are not many agreement errors in our data (three of them are marked with the sign $*$ ), they may be seen only in two-three component utterances with overtly expressed subject (more about agreement errors see in 7.).

From the beginning of observed period (the age 1;10) Roma used inflected forms (which are either frozen or rote-learnt) as well as infinitives. Forms of ten different inflected types are presented in the data in the three sections 2;00b-2;01b: SG.PF (masc., fem.) and PL.PF in the past, 3.SG. and 3.PL. in the present, all three persons in SG. in the future with PF verbs, SG. and PL. in the imperative and infinitive. At 2;00b one can see qualitative spurt in the occurrence of inflected forms: four new types of forms (all of them are rote-learnt, as we suppose) are registered. Repertoire of paradigmatic forms becomes richer. After 2;00 two cases of the use analytical future are registered in the diary.

Let us draw attention on the emergence of inflected forms of PF and IPF verbs. Forms of 2.SG.IMP and of infinitive of PF and IPF occur simultaneously. Regarding other inflectional forms, however, we notice slight differences in the time of occurrence of PFs vs. IPFs. Thus, PF forms with the past inflections emerge earlier than IPF and are used more often. The IPF verbs (davat' 'to let do smth', exat' 'to go by car', prygat' 'to jump') occur only in the protomorphological phase, starting from $2 ; 01 \mathrm{~b}$. Interesting to note that from $2 ; 00 \mathrm{~b}$ Roma starts to use PF (which have the meaning of nearest future), but the amount of lemmas is not high, only one for each data stretch (section): at 2;00b - poexat' 'to go by car', 2;01a postavit' 'to put, to place', 2;01b-dat' 'to give'. 
IPF verbs are used at the beginning mainly in 3.SG. We register the first occurrence at $1 ; 11-$ edet 'to go by car', kopaet 'to dig'; such forms of 3.SG. occur during the whole period of observation in the recordings and in the diary (except at 2;00a).

Early inflected verb forms in our data can be divided into 3 groups:

a) inflected forms, e.g. upal-PF - 'fall down-PAST.SG.MASC.' (within a) subdivision between rote-learnt and productively constructed forms should be done),

b) infinitives, e.g. kopat'-IPF- 'to dig',

c) frozen forms, that constitute the small amount of the whole corpus, e.g. ne dam-PF - "not give-PRES.1.SG".

Due to the fact that amount of verbs and their contrastive forms is rather low (there is often only one token of one lemma) we should be cautious in claiming that Roma's inflected forms are really self-constructed and not rote-learnt. And it is rather difficult to trace the movement from "quantity to quality", we mean the detachments of the period when rote-learnt forms turned to become self-constructed.

We suppose that in order to differentiate rote-learnt inflected forms from productively used (or self-constructed) inflected forms one should take into consideration several factors, one of which is the syntactic context. I mean here the (correct) use of verbs in two- and more component sentences with (overtly expressed) subjects and objects. Additionally, the level of lexical diversity of inflected forms and independence from the extralinguistic context (in another words: diversity of denoted situations) should be considered.

\subsection{Emergence of categories}

When tracing the emergence of categories it is very important to consider their complex nature: grammatical meaning and formal expression (see, for example, in Russian tradition Maslov (1978): Švedova (1980), Ceytlin (1989), Bondarko (1995), etc.). For example, aspect in Russian can be said to be a "more" lexical category, than tense and more grammatical than Aktionsarten. In the description below we treat separately the emergence of the formal marking and the grammatical meaning of some verb categories.

Table 7 Emergence of categories ${ }^{13}$

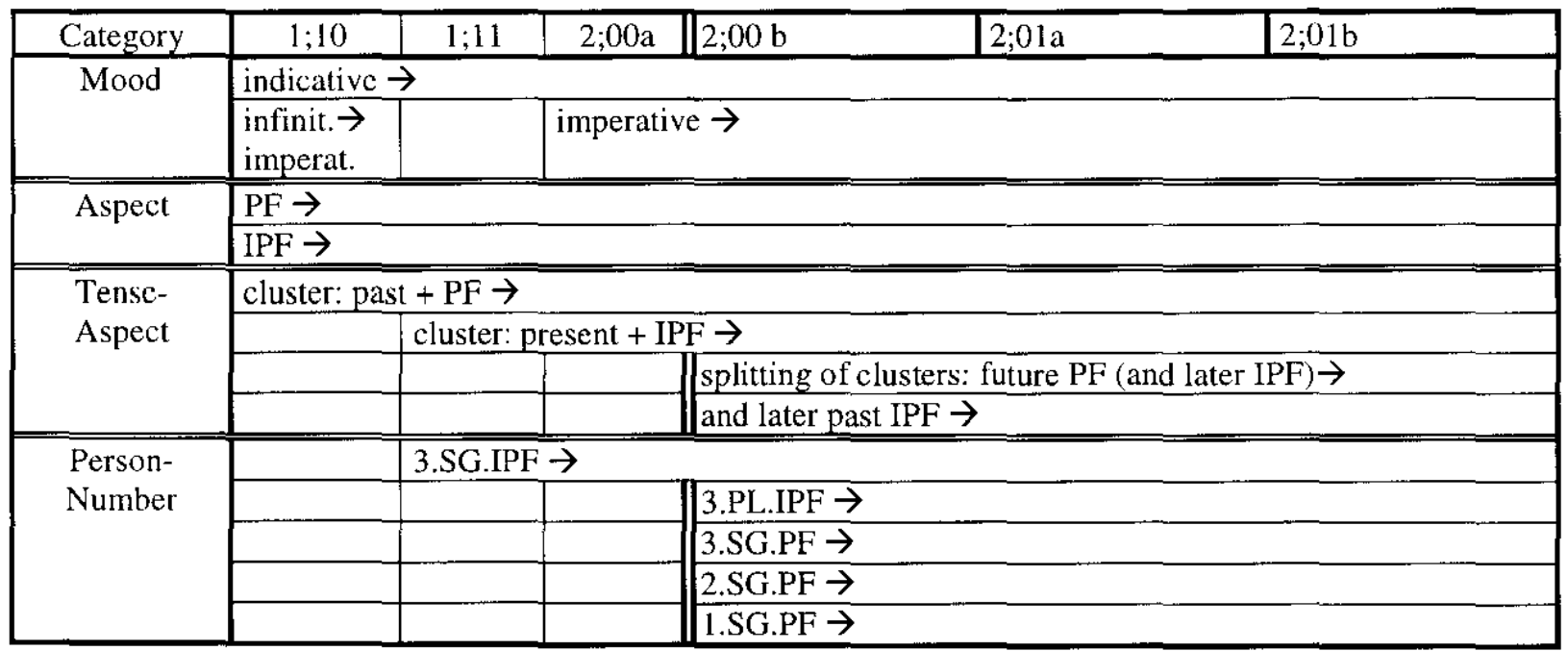

1.3 Double bold line in the table between columns $2 ; 00 \mathrm{a}$ and $2 ; 00 \mathrm{~b}$ demarcates phases: pre- and protomorphology. 


\subsubsection{Mood}

From 1;10 verbs occur in two moods: indicative and imperative, but during $1 ; 10$ and $1 ; 11$ no 'correct' imperatives with inflectional suffix $-i(t e)$ or zero suffix were used. Roma produces infinitives in the imperative meaning. First correct imperatives (with zero suffix) occur at 2;00a, for instance, kopaj-PF 'dig!' and $d a j-\mathrm{PF}$ 'give!'. The late occurrence of the correct imperative forms can be due to the fact that in order to construct an imperative form one should switch from the $\mathrm{OB}$ of the infinitive to the $\mathrm{CB}$ of the present/future. Such morphological operation is rather complicated (the switch between an $\mathrm{OB}$ and a $\mathrm{CB}$ of the infinitive may be aggravated by the root/stem alternations, like in the infinitive pis-a- $t$ ' 'to write' and imperative $p i \check{s}$ - $i$, or the infinitive otkry- $t$ ' 'to open' and the imperative $o t k r o j{ }^{14}$ ) and cannot be produced by the child in the premorphological stage. The use by the child of the significant amount of imperatives with two types of inflectional suffixes (along with other inflected forms) may be, probably, interpreted as the sign of transition from the premorphological phase to more advanced protomorphological phase.

So, the grammatical meaning of mood occurs before the correct morphological marking.

\subsubsection{Aspect (and tense)}

Aspect is probably one of the most complicated verb categories, the investigation of which in adult language and in language acquisition is characterised by the set of various (sometimes even controversial) definitions and approaches (like in Icačenko 1960, Švedova 1980: 583, Verkuyl 1993, Li and Shirai 2000, etc.). Due to the lack of space and the small data corpus that is investigated here we will remark only on the emergence of PF and IPF verbs (the emergence of grammatical aspect or viewpoint aspect, see Smith 1983, 1997) and Aktionsarten ${ }^{15}$ and leave the detailed discussion for the projected book on the acquisition of inflectional categories.

To recapitulate shortly: verbs of both aspects occur simultaneously in our corpus at the age of 1;10. First PF verbs at 1;10 and 1;11 are marked for past: upal 'fell down-SG.masc.', slomal 'broke-SG.masc.' (there is one PF verb in the infinitive: odet' 'to put on clothes'), while IPF verbs - for present: kapaet 'dig-3.SG.pres.'. PF verbs denote resultative actions, the perceived result of which was reached at the time of speech (and belong mainly to the group of achievements - in Vendler's classification). IPF verbs denote ongoing actions (that may have potential telic meaning and belong to activities or states in Vendler's classification) ${ }^{16}$. Such connection between inherent semantics of verbs (i.e, lexical aspect or Aktionsart) and tense marking has been reported for other languages as well (see, for example, Antinucci and Miller (1976) for Italian and English, Shirai \& Anderson (1995) for English, Aksu-Koç (1978) for Turkish, Champaud et al. (ms.) for French, etc.). The study of Bloom, Lifter and Hafitz (1980) reveals that children acquiring English as their mother tongue distribute inflections ing,-s and irregular selectively with different "semantic" populations of verbs 17 .

Later, at 2;00b, when the child, as we claim, enters the protomorphological stage, connections between verbs of either PF or IPF aspect and tense marking become weaker and clusters

\footnotetext{
14 In the second example the verb otkryt' 'to open' was produces by Roma variously, sometimes correctly as 'otkroj', and sometimes with a phonological error' $o k i j$ ' (clustrers of consonants 'tkr' were not produced in this period). Infinite forms of 'okit', 'kit' were used in the imperative meaning.

15 More about Aktionsarten see, for example, in Vendler 1967, Šeljakin 1987.

16 The same tendency has been reported also for more children learning Russian as their mother tongue (see, for example, Gagarina 1997, Pupynin 1998). Controversial facts are reported in Kiebzak-Mandera (1999).

17 In Russian this connection (in the early stages of language acquisition) should be even stronger; after all, the grammatical category of aspect determines important features of the semantics of the verb in Russian, as Rassudova (1982) noticed.
} 
between tense and aspect split. IPF verbs attach inflectional suffix of the past: exa- $l$ 'was going-SG.masc' and PF verbs are used in the future: postavlju 'will put-1.SG'.

The most morphotactically transparent groups of verbs that belong to Aktionsarten with the minimally expressed (by prefixes and suffixes) additional meaning comprise the early verb lexicon. These are telic verbs which denote actions, aiming to reach (successfully $=$ a result, such as kopat' 'to dig', est' 'to eat', stirat' 'to wash', etc (accomplishments). Atelic state verbs are less common: sidet' 'to sit', spat' 'to sleep'. Only several verbs (of motion) with prefix po-, denoting ingressive meaning were produced: poexat' 'to start going by car', pojti 'to start going by foot'. No verbs with semantically "complicated" affixes, like perečityvat' 'to reread - iterative', peresolit' 'to put too much salt' or nadlomit' 'to break partially, not to the end' were found.

\subsubsection{Person-Number}

Roma (as well as other children, acquiring Russian) starts with 3.SG of IPF verbs. The protomorphological stage is characterised by the occurrence of forms of 3.PL of IPF verbs and all three persons in SG of PF verbs. Unmarked forms - 3.SG.present - are the first to occur in the data.

\section{Development of MP}

We will consider now the emergence of inflected forms of certain lemmas and will try to elaborate some additional criteria (to those of Dressler and Kilani-Schoch 2000) for defining $\mathrm{MP}$ in the languages where the existence of two bases (OB and $\mathrm{CB}$ ) is crucial for the verb inflectional system. We suppose that the ability of children to switch between $\mathrm{OB}$ and $\mathrm{CB}$ may be an indicator of the higher level of children's mastering of the complexity (of morphological operations) of grammar. Such forms as pit'-IPF 'to drink' and p'jot'-PF 'drink3.SG' can be, probably, considered a true $\mathrm{MP}^{18}$; the operation to construct these two forms is more complicated as, for example, in the case of past tense: upal-MASC.SG, upala-FEM.SG, upali-PL.

The first three differently inflected forms of one PF verb upast' 'to fall down' occur already at the age of 1;11 (see above). However, we cannot consider these forms to be the first true MP. One of the reasons would be the following: all these inflected forms were created from the $\mathrm{OB}$, only by adding inflectional suffix of the past $-l$ and different markers of either feminine or masculine in SG or PL: $-a,-\varnothing$ or $-i$. At this age we do not find evidence that Roma differentiates between gender (and number). Moreover, sometimes he uses masculine and feminine endings of the verb in the wrong contexts, for example:

\%sit: A wheel (neuter gender) fell down from Roma's hands

*ROM: $\quad \mathrm{xxx}$ upal.

\%pho: $\quad$ Eee pau.

fall-PAST.MASC.SG

\%sit: Roma threw down a plastic tube (feminine gender) and watched it rolling:

*ROM: Upal.

\%pho: Pau.

fall-PAST.MASC.SG

\footnotetext{
${ }^{18}$ In case the child uses forms of $3 . S G$ of the other verbs.
} 
\%sit: Roma approaches the armchair, takes the cover (feminine gender) and throws it on the floor:

*ROM: Upali.

\%pho: $\quad$ Apai.

\section{fall-PAST.PL}

In the observed period (during 4 months) seven lemmas were used in three forms and one lemma was used in 5 forms. Only two pairs of verbs (with the same root) which differs only by prefix po-were used: exat' - poexat' and pit' - popit'. The meaning of po- in these two cases is various: ingressive and delimitative, respectively. One pair of verbs differs by means of suffix dat' - davat'. However this last couple can be hardly seen as a real aspectual pair. The verb dat' was used for a long time as a frozen form and davat' - as a rote-learnt form. Both verbs are often used by the mother.

Tables 9 and 10 give the overview of the first contrastive forms (and true MPs) of verbs at the age of 2;00 and 2;01. We suppose that verbs that have two contrastive forms and first true MP (three and more forms) consist of mainly rote-learnt forms.

Table 9 Verbs, contrastive forms and early true MP at the age of 2;00:

\begin{tabular}{|c|c|c|c|c|c|c|c|c|c|}
\hline $\begin{array}{c}2 ; 00 \mathrm{a} \text { and } \\
2 ; 00 \mathrm{~b}\end{array}$ & $\begin{array}{l}\text { English } \\
\text { translation }\end{array}$ & imperat. & $\begin{array}{c}\text { infinitiv } \\
\mathrm{e}\end{array}$ & $\begin{array}{l}\text { 1. SG. } \\
\text { PL. } \\
\text { pres./fut. }\end{array}$ & $\begin{array}{c}\text { 2. SG. } \\
\text { PL } \\
\text { pres./fut. }\end{array}$ & $\begin{array}{l}\text { 3. SG. } \\
\text { PL } \\
\text { pres./fut. }\end{array}$ & past-m & past-f & past-PL \\
\hline \multicolumn{10}{|c|}{ IPF verbs } \\
\hline kopat' & to dig & + & + & & & SG & & & \\
\hline pit' & to drink & & + & & & $\mathrm{SG}, \mathrm{PL}$ & & & \\
\hline spat' & to sleep & & + & & & SG & & & \\
\hline \multicolumn{10}{|c|}{ PF verbs } \\
\hline$d a t^{\prime}$ & to give & + & + & & & & & & \\
\hline otkryt' & to open & + & + & & & & & & \\
\hline poexat' & $\begin{array}{l}\text { to start going } \\
\text { by car }\end{array}$ & & & & SG & SG & + & & + \\
\hline pojti & $\begin{array}{l}\text { to start going } \\
\text { by foot }\end{array}$ & & & & & & + & + & \\
\hline upast' & to fall down & & & & & & + & + & \\
\hline vključit' & to switch on & + & + & & & & & & \\
\hline
\end{tabular}

First contrastive forms of nine verbs occur at 2;00b. Forms of the imperative, the infinitive, the present 3.SG. and the past tense (SG. and PL.) are mainly used. Two lemmas have three forms: kopat'-IPF 'to dig' - the imperative, the infinitive and 3.SG, pit'-PF - the infinitive, 3.SG and PL and one lemma - poexat'PF 'to start going (by car)' has four forms - 2.PL, 3.SG and past SG.MASC. and PL. These rote-learnt forms compose the first true MPs, that occur when Roma's vocabulary consists of only twenty verbs. The members of the first MPs of IPF and PF verbs are different and are determined by aspectual distinctions of verbs. MPs of IPFs consist mainly of infinitive and present, and MPs of PFs - of imperative, infinitive and past (only by one PF verb poexat' forms of two different tenses occur). 
At the age of 2;01 twelve lemmas with two and more different forms occur in the recordings and five lemmas in the diary (see Table $10^{19}$ ).

\begin{tabular}{|c|c|c|c|c|c|c|c|c|c|}
\hline $\begin{array}{c}2 ; 01 \mathrm{a} \text { and } \\
2 ; 01 \mathrm{~b}\end{array}$ & $\begin{array}{c}\text { English } \\
\text { translation }\end{array}$ & imperat. & $\begin{array}{c}\text { infinitiv } \\
\mathrm{e}\end{array}$ & $\begin{array}{c}\text { 1. SG. } \\
\text { PL. } \\
\text { pres./fut. }\end{array}$ & $\begin{array}{c}\text { 2. SG. } \\
\text { PL } \\
\text { pres./fut. }\end{array}$ & $\begin{array}{c}\text { 3. SG. } \\
\text { PL } \\
\text { pres./fut. }\end{array}$ & past-m & past- $f$ & past-PL \\
\hline \multicolumn{10}{|c|}{ IPF verbs } \\
\hline davat' & come on & SG, PL & + & & & & + & & \\
\hline exat' & to go by car & & $+*$ & & & & $+\#$ & & \\
\hline kushat & to eat & \pm & $\pm *$ & & & \# SG & & & \\
\hline myt's'a & to wash & & + & & & $\mathrm{SG}$ & & & \\
\hline pisat' & to do a poor & & $t^{*}$ & & & $\begin{array}{c}S G \\
\text { (diary) }\end{array}$ & \# & & \\
\hline pisat" & to write & & + & & & $\begin{array}{c}\mathrm{SG} \\
\text { (diary) }\end{array}$ & & & \\
\hline pit $^{\circ}$ & to drink & & + & & & $\mathrm{SG}$ & & & \\
\hline sidet & to sit & & & & & SG, PL & & & \\
\hline snimat & to put off & + & $\begin{array}{c}+ \\
\text { (diary) }\end{array}$ & & & & & & \\
\hline spat & to sleep & & + & & & $\begin{array}{c}\mathrm{SG} \\
\text { (diary) }\end{array}$ & & & \\
\hline \multicolumn{10}{|c|}{ PF verbs } \\
\hline$d a t^{\prime}$ & to give & + & $+($ diary $)$ & $\mathrm{SG}$ & & & & & \\
\hline poexat' & $\begin{array}{l}\text { to start going } \\
\text { by car }\end{array}$ & & & PL & & & + & & \\
\hline pojti & $\begin{array}{l}\text { to start going } \\
\text { by foot }\end{array}$ & & & $\begin{array}{c}\text { PL } \\
\text { (diary) }\end{array}$ & & & + & $+($ diary $)$ & + \\
\hline popit' & to drink a bit & & + & & & & + & & \\
\hline prititi & to come & & & & & $\mathbf{S G}$ & & \pm & \\
\hline upast' & to fall down & & & & & & + & + & \\
\hline vkljuchit' & to switch on & + & + & & & & & + & \\
\hline
\end{tabular}

At the age of 2;01 Roma used four verbs in three or more forms: one IPF verb davat' and three PF - dat' to give', pojti 'to start going' and vkljuchit' 'to switch on'. Beginning from 2;01 PF verbs attach not only inflections of the past tense, but also person-number suffixes, thus, number and composition of the MPs gradually changes.

Due to the small sample size (and the limited number of lemmas) only the small number of the true MPs has been found.

\section{Morphological substitutions}

No class shifts were registered in the observed period. We suppose that class shifts in Russian occur during the later stage (of transitional morphology). The same fact has been reported by Kiebzak-Mandera, Smoczyńska, and Protassova (1997), in their investigation of the acquisition of the early stages of Russian verb morphology. They wrote that "processes of class shifts and regularizations could be observed ... well after the emergence of the basics verb system. ... In the very earliest phases of building tense, aspect and mood distinctions they were extremely infrequent and did not reveal any systematic pattern".

19) Underlined, bold verbs are taken from the diary. If one form is taken from the recordings and another - from the diary, it is noted in the table: the word "diary" is written in the brackets. Asterisk * shows the agreement errors, and the sign \# points to the correct target form. For example, for the verb exat' the signs mean that Roma used infinitive instead of the target form past-masculine. 
It seems that in the case of Russian class shifts and over-regularizations (in constructing OB and $\mathrm{CB}$ forms as well as aspectual pairs of verbs) occur later than in other languages observed in this volume. The complex nature of alternations within one paradigm and in the root itself (when switching between the $\mathrm{OB}$ and the $\mathrm{CB}=$, as well as the rich system of prefixation (with numerous Aktionsarten), probably may slow down the emergence of "creative" errors in children. Only having mastered the system of verb inflections the child starts to produce overregularizations in root and stem alternations (while switching between the $\mathrm{OB}$ and the $\mathrm{CB}$ ) and in word formation.

In the observed period only several agreement errors were found ${ }^{20}$. In the early sentences with subjects Roma uses infinitive instead of inflected form of 3.SG. present or past tense, for example:

$\begin{array}{lllll}* \text { MAM: } & \text { Kogo } & \text { ty } & \text { tam } & \text { videl? } \\ & \text { whom } & \text { you } & \text { there } & \text { see-IPF.PAST.MASC. }\end{array}$

*ROM: Djadja Sergej sobachka kormit'

correct verb form: uncle sergej dog-NOM feed-INF

"Uncle Sergej fed the dog"

feed-PAST

Another example. Roma returns home from a walk,

*MAM: Gde ty byl, Roma?

where you were, Roma

'Where were you, Roma?'

$\begin{array}{lllll}\text { *ROM: } & \begin{array}{l}\text { Guljat' } \\ \text { walk-INF }\end{array} & \begin{array}{l}\text { papa, } \\ \text { father-NOM.SG }\end{array} & \begin{array}{l}\text { mašina } \\ \text { car-NOM.SG go-INF }\end{array} \\ \text { correct verb forms: } & \text { walk-PAST } & & & \text { go-PAST }\end{array}$

'Was walking with papa, was going by car'

In both cases the mother uses past tense forms in her questions. Thus, the temporal structure of the answer is in a way predetermined. The child constructs the poly-component utterances and doesnot use the "correct"-target past form (note, that Roma used already the past form of the verb exat' ). Probably, production of the poly-component (syntactically complex) utterances aggravates the construction of the inflected forms.

\section{Conclusion}

When analysing our data and making comparisons with the results presented by the other authors, we noticed some peculiarities in the acquisition of the inflectional system of Russian verbs. On the one hand, at 1;10 Roma started to use verbs with different inflections, later on we registered steady increase of different inflected forms, the verb lexicon became richer, and the number of true MPs increases. On the other hand we note "stable" use of infinitives. No class shifts (they occur later), or any formations of the analogical nature occur in the period under observation. Agreement errors are also rare (infinitive instead of PRES.3.SG or PAST.MASC forms).

Almost no mistakes in the alternations between $\mathrm{OB}$ and $\mathrm{CB}$ were registered. Roma correctly spelled the different alternations in roots and stems, probably due to the fact that many forms

20 Agreement errors are also rare in the data of Kiebzak-Mandera (1999). 
were rote-learnt. The early contrastive forms that Roma uses were not only transparent (belong not only to the $1^{\text {st }}$ productive $\mathrm{MC}$ ), but also suppletive and opaque. This may, probably, confirm the fact that the majority of the inflected forms in this stage are not selfconstructed.

The more detailed Table 11 below gives a qualitative and quantitative overview of the emergence of lemmas with two forms and true MPs:

\begin{tabular}{|l|c|c|c||c|c|c|c|c|c|}
\hline & $1 ; 10$ & $1 ; 11$ & $2 ; 00 \mathrm{a}$ & $2 ; 00 \mathrm{~b}$ & $2 ; 01 \mathrm{a}$ & $2 ; 01 \mathrm{~b}$ & $\begin{array}{c}2 ; 00 \\
\text { diary }\end{array}$ & $\begin{array}{c}2 ; 01 \\
\text { diary }\end{array}$ & $\begin{array}{c}2 ; 02 \\
\text { diary }\end{array}$ \\
\hline new verb lemmas & 3 & 5 & 4 & 8 & 9 & 10 & & 13 & 12 \\
\hline MPs with two-members & - & - & 2 & 3 & 5 & 2 & & \\
\hline $\begin{array}{l}\text { MPs with two-members: } \\
\text { whole month }\end{array}$ & - & - & & 6 & & & & \\
\hline $\begin{array}{l}\text { Threc, more members } \\
\text { MPs: whole month }\end{array}$ & - & - & & 3 & & & & \\
\hline
\end{tabular}

The last Table 12 below shows changes in the lexicon, in the verb inflection, in the development of the syntactic context and the emergence of the true MPs during two phases:

\begin{tabular}{|l|l|l|}
\hline & Premorphological phase & Protomorphological phase \\
\hline lexicon & lexicon consists of about ten verbs & $\begin{array}{l}\text { verb spurt, utterances with verbs consist 12\% of all } \\
\text { analysed utterancs }\end{array}$ \\
\hline $\begin{array}{l}\text { verb } \\
\text { inflection }\end{array}$ & $\begin{array}{l}\text { only 3.SG.IPF and PAST.PF, mainly rote- } \\
\text { learned forms, frosen forms, } \\
2-3 \text { types of inflected forms }\end{array}$ & $\begin{array}{l}\text { 3.PL. and 1.SG.IPF and PF, PAST.IPF, analytical } \\
\text { forms occur, } \\
6-9 \text { types of inflected forms }\end{array}$ \\
\hline MP & $\begin{array}{l}\text { no forms of one lemma (if any, they are not } \\
\text { true MPs) }\end{array}$ & two contrastive forms of one lemma, true MPs \\
\hline $\begin{array}{l}\text { syntactic } \\
\text { context }\end{array}$ & $\begin{array}{l}\text { one word, very rare two-component } \\
\text { utterances }\end{array}$ & two- and three-component utterances \\
\hline
\end{tabular}

In the early stages of the development of verb inflection, when rote-learnt forms prevail in the speech production, the imitative learning, as Tomasello (2000) underlines, "is a necessary and crucially important part of language acquisition". However, later, the more self-constructed inflectional forms we find in the child's speech production (and the higher will be the level of detection of morphological rules) the less important would be the role of imitative learning. In the stage of pre-morphology Roma produces mainly frozen and rote-learnt forms in the oneword utterances with the minimal variation (and the high level of transparency) of verb inflections.

Gradually, the amount of frozen forms decreases and the number and the variety of rote-learnt forms increases and reaches such critical mass which leads the child to detecting morphological operations (and rules) and to producing self-constructed inflected forms. Mastering of the grammatical rules (morphological operations) of a given language and ability to operate with them become one of the decisive factors in the further acquisition of inflectional morphology.

The emergence of frosen forms, of the first rote-learnt contrastive forms, of the selfconstructed forms and of the true MPs are steps of pre-modular morphological development. These processes of development are the corner-stones underling the further acquisition and productive use of the inflectional system. And, probably, because cognitive development of children takes place along with the acquisition of system of language and the detecting of the rules of inflectional morphology, children, unlike adults learning Russian, do not have so many obstacles in learning and use of some verb categories, such as, for example, PF and IPF aspects of verbs. 


\section{References}

Aksu-Koç, Ayhan (1978): Aspect and modality in the children's acquisition of the Turkish past tense. Berkley: University of Califomia, Dissertation.

Antinucci, Francesco / Ruth Miller (1976): How children talk about what happened. Journal of child language 3, 169-189.

Bondarko, Aleksandr V. (1995): Semantika glagol'nogo vida v russkom jazyke. (= Beitrage zur Slavistik XXIV). Frankfurt am Main, Berlin, Bern, New York, Wien. [Semantics of aspect in Russian]

Bloom, Lois / Karin Lifter / Jeremie Hafitz (1980): Semantics of verbs and the development of verb inflection in child language . Language 56/2, 386-412.

Brun, Dina / Sergej Avrutin / Marina Babyonyshev (1999): Aspect and Ist Temporal Interpretation during the optional Infinitive Stage in Russian. In: Annabel Greenhill, Heather Littlefield, \& Cheryl Tano (eds.) BUCLD 23: Proceedings of the 23rd annual Boston University Conference on Language Development, 120-131. Boston University

Ceytlin, Stella N. (1989): Detskaja rech': innovacii formoobrazovanija i slovoobrazovanija (na materiale sovremennogo russkogo jazyka). Habilitation, State Pedagogical University of Russia, St.Petersburg. [Language acquisition: inflectional and derivational innovations (the case of modern Russian)]

Champaud, Christian / Wolfgang U. Dressler / Maria Sedlak / Natalia Gagarina (ms. of the report) Acquisition of verbal Categories in French, German, Russian. Paper presented at the conference in Rennes, France, in September, 1997.

Dressler, Wolfgang U. / Natalia Gagarina (1999): Basic questions in establishing the verb classes of contemporary Russian. In: L.Fleishman et al. (eds.) Essays in poetics, Literary History and Linguistics. Festschrift V.V. Ivanov, 754 - 760. Moscow: OGI.

Gagarina, Natalia (1997): Aspektual'naja semantika i funkcionirovanije vidov russkogo glagola $v$ detskoj rechi, Unpublished PhD Dissertation, Hercen State Pedagogical University of Russia, St.Petersburg. [Aspectual semantics and functioning of the aspects of Russian verbs in language acquisition].

- (2000): The acquisition of aspectuality by Russian children: the early stages. ZAS Papers in Linguistics 15, 232-246.

Gvozdev, Aleksandr N. (1949): Formirovanije u rebenka grammaticheskogo stroja russkogo jazyka. Moscow: Akad. Pedag. Nauk RSFSR. [The construction of the grammatical system of Russian by the child].

Isačenko, A.N. (1960): Grammatičeskij stroj russkogo jazaka v sopostavlenii s slovackim. Morfologija, Čast' 2. Bratislava: Izd-vo slovackoj Akademii Nauk. [Grammatical system of Russian language in comparison with Slovak].

Kiebzak-Mandera, Dorota (1999): Kształtowanie się systemu werbalnego u dzieci rosyjskojęzycznych. Analiza porównawcza Unpublished doctoral dissertation. Jagellonian University, Kraków. [Formation of the verb system in Russian-speaking children. A comparative study]

- / Magdalena Smoczyńska / Ekaterina Protassova (1997): Acquisition of Russian verb morphology: the early stages. In: Wolfgang U. Dressler (ed.), with the production assistance of Ralf Vollmann: Studies in pre- and protomorphology, 101-114. Wien: Verlag der Österreichischen Akad. der Wiss., (Sitzungsberichte der Österreichischen Akademie der Wissenschaften: Philos.-histor.).

Kilani-Schock, Marianne / Anna De Marco / Anastasia Christofidou / Maria Vassilakou / Ralf Vollmann / Wolfgang U. Dressler (1997): On the demarcation of phases in early morphology acquisition in four languages. In: Jacek Fisiak (ed.) Papers and studies in contrastive linguistics 33, 9-15. Poznań: Adam Mickewicz University.

- / Wolfgang U. Dressler (2000): The emergence of verb paradigms in two French corpora as an illustration of general problems of pre- and protomorphology. Poster presented at the $9^{\text {th }}$ Int. Morphology Meeting, February.

Klein, Wolfgang (1995): A time-relational analysis of Russian Aspect. Language 71, 669-695.

Li, Ping / Yasuhiro Shirai (2000): Studies in Language Acquisition. In: Peter Jordens (ed). The Acquisition of Lexical and Grammatical Aspect 16. New York, Berlin: de Gruyter.

Maslov, Jurij S. (1978): Ocherki po aspektologii. Leningrad: LGU. [Drafts on aspectuality]. 
Pupynin, Jurij A. (1998): Elementy vido-vremennoj sistemy v detskoj rechi. Voprosy jazykoznanija 2, 102-116. [The elements of the system of tense and aspect in language acquisition]

Rassudova, Ol'ga P. (1982): Upotreblenie vidov russkogo glagola v sovremennom russkom jazyke.M.: Russkij jazyk. [The use of verb aspect in the contemporary Russian]

Shirai, Yasuhiro / Roger Andersen (1995): The acquisition of tense-aspect morphology: A prototype account. Language 71, 743-763.

Smith, Carlota (1983): A theory of aspectual choice. Language, 59, 479 - 501.

- (1997): The Parameter of Aspect. Second Edition. Dordrecht: Kluwer.

Šeljakin Mihail A. (1987): Sposoby dejstvija $v$ pole limitativnosti. In: Teorija funkcional'noj grammatiki. Leningrad: Nauka, 63-85. [Actionsarten in the field of limitedness]

Švedova, Natalja J. (Ed.) (1980): Russkaja grammatika: V 2-x tt. Moskva: Nauka, AN SSSR. [Russian Grammar]

Tomasello, Michael (2000): Acquiring syntax is not what you think. In: Doroty V.M. Bishop and Laurence B. Leonard (eds.) Speech and Language impairments in children: Causes, characteristics, intervention and outcome. Psychology Press.

Vendler, Zeno (1967): Verbs and times. Linguistics in philosophy. Cornell University Press: Ithaca, New York.

Verkuyl, Henk J. (1993): A theory of aspectuality (The interaction between temporal and atemporal structure). Cambridge: Cambridge University Press. 


\section{Appendix}

Quantitative overview of the produced forms in recordings and diary is given in Table 5.1. and Table 6.1.

Table 5.1. Production of infinitive and inflected verb forms - recordings

\begin{tabular}{|c|c|c|c|c|c|c|c|c|c|c|c|c|c|c|c|c|}
\hline \multirow[t]{3}{*}{ age } & \multirow[t]{3}{*}{ aspect } & \multirow{3}{*}{$\begin{array}{l}\text { lemma } \\
\text { /types/ } \\
\text { tokens }\end{array}$} & \multirow{3}{*}{$\begin{array}{l}\text { frosen } \\
\text { forms } \\
21\end{array}$} & \multicolumn{2}{|c|}{ imperat. } & \multirow[t]{3}{*}{ inf. } & \multicolumn{6}{|c|}{ present (future for PF verbs) } & \multicolumn{4}{|c|}{ past } \\
\hline & & & & \multirow{2}{*}{$\begin{array}{l}2 . \\
\text { SG }\end{array}$} & \multirow{2}{*}{$\begin{array}{r}2 . \\
\text { PL }\end{array}$} & & \multicolumn{3}{|c|}{ SG } & \multicolumn{3}{|c|}{$\mathbf{P L}$} & \multicolumn{3}{|c|}{ SG } & \multirow[t]{2}{*}{ PL } \\
\hline & & & & & & & 1. & 2. & 3. & 1. & 2. & 3. & fem & mas & neu & \\
\hline \multirow[t]{3}{*}{$1 ; 10$} & IPF & $1 / 1 / 1$ & & & & $1 / 1$ & & & & & & & & & & \\
\hline & PF & $2 / 2 / 3$ & & & & $1 / 1$ & & & & & & & & $1 / 2$ & & \\
\hline & all verbs & $3 / 2 / 4$ & $2 / 6$ & & & $2 / 2$ & & & & & & & & $1 / 2$ & & \\
\hline \multirow[t]{3}{*}{$1 ; 11$} & IPF & $2 / 1 / 2$ & & & & & & & $2 / 2$ & & & & & & & \\
\hline & $\mathrm{PF}$ & $4 / 4 / 27$ & $1 / 2$ & & & $1 / 1$ & & & & & & & $2 / 7$ & $2 / 18$ & & $1 / 1$ \\
\hline & all verbs & $6 / 5 / 29$ & $1 / 2$ & & & $1 / 1$ & & & $2 / 2$ & & & & $2 / 7$ & $2 / 18$ & & $1 / 1$ \\
\hline \multirow[t]{3}{*}{$\begin{array}{l}2 ; 00 \\
\mathrm{a}\end{array}$} & IPF & $2 / 2 / 3$ & & $1 / 2$ & & $1 / 1$ & & & & & & & & & & \\
\hline & $\mathrm{PF}$ & $5 / 4 / 19$ & $1 / 11$ & $1 / 5$ & & $1 / 2$ & & & & & & & $2 / 3$ & $3 / 9$ & & \\
\hline & all verbs & $7 / 4 / 22$ & $1 / 11$ & $2 / 7$ & & $2 / 3$ & & & & & & & $1 / 3$ & $3 / 9$ & & \\
\hline \multirow[t]{3}{*}{$\begin{array}{l}2 ; 00 \\
\mathrm{~b}\end{array}$} & IPF & $7 / 5 / 18$ & $1 / 1$ & $1 / 2$ & & $5 / 5$ & & & $4 / 9$ & & & $1 / 1$ & & $1 / 1$ & & \\
\hline & PF & $10 / 7 / 32$ & & $2 / 3$ & & $2 / 3$ & & $1 / 1$ & $1 / 1$ & & & & $2 / 3$ & $5 / 16$ & & $2 / 5$ \\
\hline & all verbs & $17 / 8 / 50$ & $1 / 1$ & $3 / 5$ & & $7 / 8$ & & $1 / 1$ & 5/10 & & & $1 / 1$ & $2 / 3$ & $6 / 17$ & & $2 / 5$ \\
\hline \multirow[t]{3}{*}{$\begin{array}{l}2 ; 01 \\
\mathrm{a}\end{array}$} & IPF & $9 / 5 / 26$ & & $2 / 4$ & $1 / 2$ & $\begin{array}{l}3 / 7 \\
1 * / 1\end{array}$ & & & $3 / 11$ & & & $1 / 1$ & & & & \\
\hline & PF & $7 / 5 / 42$ & $1 / 5$ & $3 / 8$ & & $2 / 4$ & $2 / 6$ & & & & & & $2 / 7$ & $3 / 17$ & & \\
\hline & all verbs & $16 / 8 / 68$ & $1 / 5$ & $5 / 12$ & $1 / 2$ & $\begin{array}{l}5 / 11 \\
1 * / 1 \\
\end{array}$ & $2 / 6$ & & $3 / 11$ & & & $1 / 1$ & $2 / 7$ & $3 / 17$ & & \\
\hline \multirow[t]{3}{*}{$\begin{array}{l}2 ; 01 \\
\text { b }\end{array}$} & IPF & $14 / 4 / 20$ & & $1 / 2$ & & $\begin{array}{l}6 / 8 \\
2 * / 2\end{array}$ & & & $5 / 5$ & & & & & $2 / 3$ & & \\
\hline & $\mathrm{PF}$ & $3 / 3 / 4$ & & & & $1 / 2$ & & & & & & & $1 / 1$ & & & $1 / 1$ \\
\hline & all verbs & $17 / 5 / 24$ & & $1 / 2$ & & $\begin{array}{l}7 / 10 \\
2 * / 2\end{array}$ & & & $5 / 5$ & & & & 1/1 & $2 / 3$ & & $1 / 1$ \\
\hline
\end{tabular}

Table 6.1. Production of infinitive and inflected verb forms - diary

\begin{tabular}{|c|c|c|c|c|c|c|c|c|c|c|c|c|c|c|c|c|}
\hline & \multirow[t]{3}{*}{ aspect } & \multirow{3}{*}{$\begin{array}{l}\text { lemma } \\
\text { /types/ } \\
\text { tokens }\end{array}$} & \multicolumn{2}{|c|}{ imperat. } & \multirow[t]{3}{*}{ inf. } & \multicolumn{6}{|c|}{ present (future for PF verbs) } & \multicolumn{4}{|c|}{ past } & \multirow{3}{*}{$\begin{array}{l}\text { comp. } \\
\text { future } \\
\text { (IPF } \\
\text { verbs) }\end{array}$} \\
\hline & & & \multirow{2}{*}{$\begin{array}{l}2 . \\
\text { SG }\end{array}$} & \multirow{2}{*}{$\begin{array}{l}2 . \\
\text { PL }\end{array}$} & & \multicolumn{3}{|c|}{ SG } & \multicolumn{3}{|c|}{ PL } & \multicolumn{3}{|c|}{ SG } & \multirow[t]{2}{*}{ PL } & \\
\hline & & & & & & 1. & 2. & 3. & 1. & 2. & 3. & fem & mas & neu & & \\
\hline \multirow[t]{3}{*}{$2 ; 00$} & IPF & $6 / 3 / 6$ & $2 / 2$ & & $3 / 3$ & & & $1 / 1$ & & & & & & & & \\
\hline & PF & $3 / 2 / 12$ & $2 / 10$ & & $2 / 2$ & & & & & & & & & & & \\
\hline & all verbs & $9 / 3 / 18$ & $4 / 12$ & & $5 / 5$ & & & $1 / 1$ & & & & & & & & \\
\hline \multirow[t]{3}{*}{$2 ; 01$} & IPF & $22 / 6 / 33$ & $4 / 4$ & & $\begin{array}{l}6 / 10 \\
1 * / 1\end{array}$ & $1 / 1$ & & $9 / 16$ & & & $1 / 1$ & & $1 / 1$ & & & \\
\hline & $\mathrm{PF}$ & $11 / 5 / 13$ & & & $2 / 7$ & & & $1 / 1$ & $2 / 5$ & & & $1 / 1$ & $\begin{array}{l}8 / 12 \\
1 * / 1\end{array}$ & & & $1 / 2,2 / 2$ \\
\hline & all verbs & $33 / 7 / 46$ & 4/4 & & 8/17 & $1 / 1$ & & $10 / 17$ & $2 / 5$ & & $1 / 1$ & $1 / 1$ & 9/13 & & & $3 / 4$ \\
\hline \multirow[t]{3}{*}{$2 ; 02$} & IPF & $12 / 3 / 15$ & $6 / 7$ & & & $1 / 1$ & & $5 / 9$ & & & & & & & & \\
\hline & $\mathrm{PF}$ & $7 / 5 / 14$ & $1 / 1$ & & $4 / 4$ & & & & $1 / 2$ & & & $1 / 3$ & $4 / 4$ & & & $2 / 3,2 / 2$ \\
\hline & all verbs & $19 / 7 / 29$ & $7 / 8$ & & 4/4 & $\mathbf{1} / \mathbf{1}$ & & $5 / 9$ & $1 / 2$ & & & $1 / 3$ & $4 / 4$ & & & $4 / 5$ \\
\hline
\end{tabular}

21 Fraction from two figures shows the number of lemmas and tokens. 
